\title{
PENERAPAN LANGKAH-LANGKAH KESELAMATAN PASIEN MATERNITAS (IBU HAMIL)
}

\author{
Angel Ester Simanjuntak / 181101142 \\ angelester85@,gmail.com
}

\begin{abstract}
ABSTRAK
Latar Belakang : Keselamatan (safety) telah menjadi isu global termasuk juga untuk rumah sakit. Ada enam sasaran keselamatan pasien di rumah sakit yaitu ketepatan identifikasi, peningkatan komunikasi efektif, peningkatan keamanan obat yang perlu diwaspadai, kepastian tepat lokasi, tepat prosedur, tepat pasien operasi, pengurangan resiko infeksi terkait pelayanann kesehatan pengurangan resiko pasien jatuh (Depkes, 2011). Tujuan : untuk mengetahui penerapan langkah-langkah keselamatan pasien maternitas terutama ibu hamiMetode : analisis data sekunderHasil : Menurut jurnal PENERAPAN MODEL KEPERAWATAN NEED FOR HELP WIEDENBACH DAN SELF CARE OREM PADA ASUHAN KEPERAWATAN IBU HAMIL DENGAN KONTRAKSI DINI menyatakan bahwa Asuhan keperawatan yang dilakukan pada ibu hamil dengan kontraksi dini tidak hanya merupakan aplikasi peran sebagai pemberi pelayanan keperawatan, namun juga sebagai kolaborator, komunikator dan koordinator pada saat bekerjasama dengan tim kesehatan lainnya.Pembahasan : Keperawatan maternitas merupakan salah satu bentuk pelayanan profesional keperawatan yang ditujukan kepada wanita pada masa usia subur (WUS) berkaitan dengan sistem reproduksi, kehamilan, melahirkan, nifas, antara dua kehamilan dan bayi baru lahir sampai umur 40 hari, beserta keluarganya, berfokus pada pemenuhan kebutuhan dasar dalam beradaptasi secara fisik dan psikososial untuk mencapai kesejahteraan keluarga dengan menggunakan pendekatan proses keperawatan. Penutup : penerapan langkah-langkah keselamatan pasien maternitas(ibu hamil) sangat penting. Ibu hamil dapat mengalami resiko jika tidak dilakukan penerapan patient safety dengan baik.
\end{abstract}

Kata Kunci : Keselamatan Pasien, Maternitas, Ibu Hamil 


\section{LATAR BELAKANG}

Keperawatan

maternitas

merupakan salah satu bentuk pelayanan profesional keperawatan yang ditujukan kepada wanita pada masa usia subur (WUS) berkaitan dengan sistem reproduksi, kehamilan, melahirkan, nifas, antara dua kehamilan dan bayi baru lahir sampai umur 40 hari, beserta keluarganya, berfokus pada pemenuhan kebutuhan dasar dalam beradaptasi secara fisik dan psikososial untuk mencapai kesejahteraan keluarga dengan menggunakan pendekatan proses keperawatan.

Keselamatan pasien rumah sakit adalah suatu sistem yang diterapkan untuk mencegah terjadinya cedera akibat perawatan medis dan kesalahan pengobatan melalui suatu sistem assesment resiko, identifikasi dan pengelolaan faktor risiko, pelaporan dan analisis insiden, kemampuan belajar dan tindak lanjut dari insident serta implementasi solusi untuk meminimalkan timbulnya risiko (Dep Kes RI, 2006).

Keselamatan (safety) telah menjadi isu global termasuk juga untuk rumah sakit. Ada enam sasaran keselamatan pasien di rumah sakit yaitu ketepatan identifikasi, peningkatan komunikasi efektif, peningkatan keamanan obat yang perlu diwaspadai, kepastian tepat lokasi, tepat prosedur, tepat pasien operasi, pengurangan resiko infeksi terkait pelayanann kesehatan pengurangan resiko pasien jatuh (Depkes, 2011).

Keenam aspek tersebut sangat penting untuk dilaksanakan di setiap rumah sakit. Namun harus diakui kegiatan institusi rumah sakit dapat berjalan apabila adapasien. Keselamatan pasien merupakan prioritas utama untuk dilaksanakan dan hal tersebut terkait dengan isu mutu dan citra perumahsakitan (Depkes, 2011).

Keselamatan pasien dapat menimbulkan insiden. Insiden keselamatan pasien merupakan suatu kejadian yang tidak disengaja dan akan mengakibatkan cedera yang dapat dicegah pada pasien.

Rumah sakit harus mendidik pasien dan keluarganya tentang kewajiban dan tanggung pasien dalam asuhan kesehatan pasien. Keselamatan pasien dalam pemberian pelayanan dapat di tingkatkan dengan keterlibatan pasien yang merupakan patner dalam proses pelayanan. Karena itu di rumah sakit harus ada sistem dan mekanisme mendidik pasien dan keluarganya tentang kewajiban dan tanggung jawab pasien dalam asuhan pasien.

Rumah sakit merupakan suatu instansi yang memberikan layanan 
kesehatan. Rumah Sakit harus mampu menciptakan kualitas pelayanan yang optimal kepada pasien. Salah satu cara untuk mewujudkan pelayanan yang optimal ialah dengan memperhatikan keselamatan pasien.

Patient Safety atau keselamatan pasien adalah suatu system yangmembuat asuhan pasien di rumah sakit menjadi lebih aman. Sistemini men5egah terjadinya 5edera yang disebabkan oleh kesalahanakibat melaksanakan suatu tindakan atau tidak mengambil tindakanyang seharusnya diambil.

\section{TUJUAN}

Kajian ini bertujuan untuk mengetahui penerapan langkah-langkah keselamatan pasien maternitas terutama ibu hamil

\section{METODE}

Metode yang digunakan dalam kajian menggunakan analisis data sekunder yang dimana kajian bersumber dari jurnal dan buku.

\section{HASIL}

Menurut jurnal PENERAPAN MODEL KEPERAWATAN NEED FOR HELP WIEDENBACH DAN SELF CARE OREM PADA ASUHAN KEPERAWATAN IBU HAMIL
DENGAN KONTRAKSI DINI menyatakan bahwa Asuhan keperawatan yang dilakukan pada ibu hamil dengan kontraksi dini tidak hanya merupakan aplikasi peran sebagai pemberi pelayanan keperawatan, namun juga sebagai kolaborator, komunikator dan koordinator pada saat bekerjasama dengan tim kesehatan lainnya.

Pelaksanaan praktik residensi juga memberikan kesempatan untuk menerapkan peran sebagai pengelola yaitu dengan melaksanakan manajemen keperawatan dengan metoda tim, melakukan koordinasi dengan tenaga kesehatan lainnya, membantu membuat standar asuhan keperawatan melalui perumusan clinical pathway pada kasus Preeklampsi berat.Selain itu, peran sebagai pengelola suhan keperawatan dan sebagai peneliti diwujudkan dengan pemberian asuhan keperawatan pada lima kasus ibu hamil dengan kontraksi dini yang dilakukan di dua rumah sakit saat melaksanakan praktik residensi.

Peran sebagai educator dilakukan pada saat memberikan pendidikan kesehatan pada klien. Peran sebagai change agent diwujudkan pada saat melaksanakan proyek inovasi di setiap lahan praktik yang digunakan. 


\section{PEMBAHASAN}

Keperawatan

maternitas

merupakan salah satu bentuk pelayanan profesional keperawatan yang ditujukan kepada wanita pada masa usia subur (WUS) berkaitan dengan sistem reproduksi, kehamilan, melahirkan, nifas, antara dua kehamilan dan bayi baru lahir sampai umur 40 hari, beserta keluarganya, berfokus pada pemenuhan kebutuhan dasar dalam beradaptasi secara fisik dan psikososial untuk mencapai kesejahteraan keluarga dengan menggunakan pendekatan proses keperawatan.

Menurut Reeder(1997), peran perawat dalam keperawatan maternitas adalah:

1. Pelaksana: Meningkatkan kesehatan yaitu mengidentifikasi

dan memaksimalkan

kemampuan klien yang spesifik dan unik untuk mencapai hasil maksimal dan hidup yang berkwalitasatau kematian yang tenang; mengurangi resiko sakit, meningkatkankebiasaan gaya hidup sehat mempertahankan keadaan optimal.

2. Pendidik: Bertanggung jawab dalam hal pendidikan dan pengajaran ilmu keperawatan dan tenagakesehatan lainnya, bagi klien yang dalam keadaan tidak tahu menjadi tahu, tidak maumenjadi mau dan tidak mampu menjadi mampu

3. Konselor: Perawat sebagai seorang yang mempunyai keahlian dalam memberikan konseling kepada klien,konselor bertanggungjawab memberikan layanan dan konseling.

4. Role Model bagi para ibu: Panutan bagi para ibu-ibu yang sedang menjalankan keperawatan maternitas.

5. Role model bagi teman sejawat: Panutan sesame perawat atau saling bekerja sama antar perawat.

6. Perumus masalah: Mengetahui masalah-masalah yang muncul pada pasien dan merumuskan masalah tersebut.

keselamatan pasien (patient safety) dapat diterapkan pada keperawatan maternitas terutama pada ibu hamil. Beberapa hal yang perlu perawat perhatikan agar dapat melakukan penerapan keselamatan pasien kepada perawatan maternitas, yaitu:

1. Mengidentifikasi Ibu hamil: perawat melakukan pengkajian tentang identitas ibu hamil. Ketika pengkajian data, perawat juga melakukan pemeriksaan kepada ibu hamil untuk dapat mengidentifikasi kesehatan ibu dan janin. Pemeriksaan yang dilakukan adalah mengukur TTV, melakukan palpasi 
leopold, dan melakukan aukskultasi

DJJ.

2. Adanya komunikasi yang efektif: berlangsungnya komunikasi yang tepat dalam maternitas dapat membantu kefektifan dalam dunia keperawatan maternitas.

Komunikasi efektif dapat dilakukan antara perawat ke dokter, perawat ke perawat, perawat ke pasien maupun dokter ke pasien. Perawat dapat menjelaskan tentang keadaan kesehatan si ibu dan janinnya kepada suami dan ibu hamil. Komunikasi efektif antara perawat ataupun dokter ke pasien dalam hal ini ibu hamil dapat membantu ibu sejak pra konsepsi untuk mengorganisasikan perasaannya, pikirannya untuk menerima dan memelihara kehamilannya.

3. Obat-obatan: Ibu hamil sensitif dengan obat, maka dari itu perawat harus teliti dalam pemberian obat

\section{PENUTUP}

dari kajian ini dapat disimpulkan bahwa penerapan langkah-langkah keselamatan pasien maternitas(ibu hamil) sangat penting. Ibu hamil dapat mengalami resiko jika tidak dilakukan penerapan patient safety dengan baik.

\section{REFERENSI}

Ali, Z. (2002). Dasar-Dasar Keperawatan, Profesional. Jakarta: Widya Medika.

Budiati, d. (2014). PENERAPAN MODEL KEPERAWATAN NEED FOR HELP WIEDENBACH DAN. JURNAL KEPERAWATAN, Volume 5, Nomor 2 , $173-177$.

Fauziah. (2015). Buku AjarKeperawatan Maternitas, Vol.2. Jakarta: Kencana.

Hamilton, P. (1995). Dasar-Dasar Keperawatan Maternitas. Jakarta: EGC.

Helen, F. (1999). Perawatan Maternitas, Edisi 2. Jakarta: EGC.

Kamil, H. (2016). PATIENT SAFETY. Idea Nursing Journal Vol 1, No 1, 20872879.

karjatin. (2016). MODUL BAHAN AJAR CETTAK KEPERAWATAN, KEPERAWATAN MATERNITAS. KEMENTERIAN KESEHATAN REPUBLIK INDONESIA.

Rachmawati, A. R. (2017). Analisis Pelaksanaan Tujuh Langkah Menuju Keslamatan Pasien Di Rumah Sakit Islam Sultan Agung Semarang. Jurnal Kesehatan Masyarakat (e-journal) Volume 5, Nomor 1 , 2356-3346. 
Rahayu. (2016). Panduan Praktikum

Keperawatan Maternitas. Yogyakarta: DEEPUBLISHI.

Simamora , R. H. (2018). Buku Ajar Keselamatan Pasien Melalui Timbang Terima Pasien berbasis Komunikasi Efektif: SBAR.

Triwibowo, C., Yuliawati, S., \& Husna, N. A. (2016). HANDOVER SEBAGAI UPAYA PENINGKATAN KESELAMATAN PASIEN (PATIENT SAFETY) DI RUMAH SAKIT. Jurnal Keperawatan Soedirman (The Soedirman Journal of Nursing), Volume 11, No.2, Juli

Wagiyo. (2016). Asuhan Keperawatan Antenatal, Intranatal dan Bayi Baru Lahir Fisiologis dan Patologis. Yogyakarta: CV. ANDI OFFSET.

Winkjosastro. (2007). Ilmu Kandungan, cetakan kelima. Jakarta: YAYASAN BINA PUSTAKA SARWONO PRAWIRAHARDJO.

Yusuf, M. (2017). Penerapan Patient Safety Di Ruang Rawat Inap Rumah Sakit Umum Daerah Dr. Zainoel. Jurnal Ilmu Keperawatan 5:1 , 2338-6371. 